\title{
THE TRANSFORMATION IN THE LAY-OUT OF BUILDING AND SPATIAL MASS IN THE BLOCKS AND CORRIDORS IN THE CITY CENTER AREA STUDY CASE: PASAR BARU IN BANDUNG
}

\author{
${ }^{1}$ Agnes Trisia. ${ }^{2}$ Dr. Ir. Yasmin Suriansyah, MSP. \\ ${ }^{1}$ Student in the Bachelor's (S-1) Study Program in Architecture \\ at Parahyangan Catholic University \\ ${ }^{2}$ Senior lecturer in the Bachelor's (S-1) Study Program in Architecture \\ at Parahyangan Catholic University
}

\begin{abstract}
The overly rapid development of commercial functions has changed the lay-out (massing) of Pasar Baru and its environs, along with the horizontal and vertical expansion of buildings, causing a typomorphological transformation, leading to problems with the lay-out in terms of scale, façade, orientation, and building height. This research study is followed by a description of this lay-out and its impact on the blocks and corridors of Jalan Otto Iskandar Dinata (Otista) by way of the qualitative-descriptive survey method, complemented by study of the relevant background literature, and a discussion of the typo-morphological transformation of Jalan Otista. The changes have impacted the blocks and corridors. The former came in the shape of the residential pockets being wedged together, a change of circulation in these pockets, disorientation of the block mass, and asymmetry or discrepancy observed in the building scale. The latter took the shape of changes in the building façades that tend to be heterogeneous, assymetry or discrepancy in the building scale, the interrupted arcade and non-defined entrance doors to alleys.

The conclusion shows that this area displays a typo-morphology of building façades that is relatively heterogeneous. This area will experience vertical building with a larger building mass of blocks that is relatively larger in volume. In turn, this will cause the residential pockets within the blocks to disappear although some of these are bound to survive. This study may provide useful input for the municipal government in anticipating and overcoming the problems surrounding the spatial lay-out and urban planning of a developing city.
\end{abstract}

\section{TRANSFORMASI TATANAN MASSA BANGUNAN DAN RUANG PADA BLOK DAN KORIDOR DI KAWASAN PUSAT PERKOTAAN STUDI KASUS: PASAR BARU, BANDUNG}

\author{
${ }^{1}$ Agnes Trisia. ${ }^{2}$ Dr. Ir. Yasmin Suriansyah, MSP. \\ ${ }^{1}$ Mahasiswi S1 Program Studi Arsitektur Universitas Katolik Parahyangan. \\ ${ }^{2}$ Dosen Pembimbing S1 Program Studi Arsitektur Universitas Katolik Parahyangan.
}

\footnotetext{
${ }^{1}$ Corresponding author: agnes_trisia@yahoo.com
} 


\begin{abstract}
Abstrak- Perkembangan fungsi komersial yang berkembang terlalu cepat menyebabkan terjadinya berbagai perubahan tata massa bangunan pada kawasan Pasar Baru dan sekitarnya. Perluasan telah menyebabkan terjadi transformasi tipo-morfologi kawasan. Munculnya fenomena-fenomena baru menyebabkan terjadinya berbagai permasalahan pada tata ruang kawasan, baik dari segi skala, fasad, orientasi dan ketinggian bangunan. Merupakan sarana untuk menelaah dan mendeskripsikan perkembangan tata massa bangunan dan dampak apa saja yang muncul pada blok dan koridor Jalan Otto Iskandar Dinata di kawasan Pasar Baru. Metode yang digunakan adalah metode pendekatan kualitatif berupa metode survei deskriptif dan metode literatur. Transformasi tipo-morfologi yang terjadi tahun 1990-2015 di Kawasan Pasar Baru dan sekitarnya menjadi dasar pembahasan sehingga ini diperoleh pemahaman yang lebih dalam mengenai transformasi tata massa bangunan dan ruang pada kawasan. Transformasi tersebut meliputi transformasi blok dan transformasi koridor Jalan Otto Iskandar Dinata. Terjadi perubahan tata massa dan ruang yang menyebabkan berbagai dampak pada blok dan koridor. Penghimpitan kantong permukiman, perubahan sirkulasi pada kantong, disorientasi blok massa dan kesenjangan skala bangunan sehingga terjadi perubahan fasad bangunan yang cenderung heterogen, kesenjangan skala bangunan, terputusnya arcade, dan munculnya pintu masuk gang yang terdefinisi. Berdasarkan penelitian ini dapat disimpulkan bahwa kawasan tersebut memiliki tipo-morfologi fasad bangunan yang relatif heterogen. Kawasan tersebut akan mengalami pembangunan ke arah vertikal dengan blok massa bangunan yang relatif lebih besar. Hal ini akan menyebabkan kantong permukiman yang berada di dalam blok menghilang maupun tetap bertahan. Diharapkan skripsi ini dapat menjadi masukan yang berguna bagi pemerintah daerah dalam mengantisipasi dan mengatasi permasalahan tata ruang kota yang berkembang.
\end{abstract}

Kata Kunci: transformasi, tata massa, blok, koridor, Pasar Baru

\title{
1 PENDAHULUAN
}

Pasar Baru merupakan kawasan yang terkenal sebagai pusat komersial pertama di Bandung. Seiring dengan berjalannya waktu, fungsi komersial pada kawasan tersebut berkembang dengan pesat. Hal tersebut menyebabkan terjadinya perubahan fungsi kawasan menjadi area perdagangan. Menguatnya fungsi komersial pada kawasan tersebut menyebabkan kebutuhan akan luas lantai bangunan bertambah, sehingga terjadi pelebaran bangunan ke arah horizontal maupun vetikal. Pelebaran tersebut mengakibatkan terjadinya pembagian dan penggabungan kavling yang pada akhirnya menyebabkan transformasi tata massa pada inner block dan outer block. Berdasarkan masalah yang telah diidentifikasikan di atas, berikut ini dirumuskan pokok-pokok persoalan yang dibahas, diteliti, dan dipecahkan yaitu sebagai berikut: (a) Bagaimana perubahan tata massa bangunan mempengaruhi tipo-morfologi blok dan koridor Jalan Otto Iskandar Dinata pada kawasan Pasar Baru? (b) Dampak apa saja yang muncul akibat terjadinya transformasi tata masa bangunan pada blok dan koridor Jalan Otto Iskandar Dinata di kawasan Pasar Baru?

Penelitian ini bertujuan untuk menelaah dan mendeskripsikan perkembangan tata massa bangunan pada blok dan koridor Jalan Otto Iskandar Dinata pada kawasan komersial pusat kota, tepatnya pada kawasan Pasar Baru. Adapun manfaat penelitian ini diharapkan dapat menjadi landasan berpijak bagi peneliti lainnya yang meneliti perubahan bentuk tatanan tipomorfologi kawasan Pasar Baru. Penelitian ini diharapkan pula dapat menjadi masukkan bagi pengelolah tata ruang kota dalam menghadapi perkembangan tatanan pada kawasan pusat kota, sehingga dapat dilakukan pembenahan ulang kawasan dengan memperhatikan kecenderungan perubahan yang terjadi.

Skripsi ini menggunakan metode pendekatan kualitatif berupa metode survei desktriptif dan metode literatur. Metode survei deskriptif dilakukan dengan cara observasi langsung terhadap objek studi, sedangkan metode literatur dilakukan dengan pengumpulan data yang mengacu pada dokumen penelitaian Prof. Sandi Siregar. Adapun proses yang dilakukan meliputi pengumpulan data dan analisa. Pengumpulan data meliputi studi literatur mengenai isu dan pengertian transformasi, sejarah perkembangan kawasan Pasar Baru, teori-teori tata 
massa, serta mengumpulkan data berdasarkan kenyataan di lapangan melalui survei maupun wawancara langsung dengan penduduk. Proses analisa menggunakan metoda tipo-morfologi, yaitu suatu metoda untuk mempelajari suatu objek arsitektur dengan menganalisa secara visual hal-hal yang berkaitan dengan tipo-morfologi di kawasan Pasar baru. Hasil analisa tersebut kemudian dibandingkan secara sinkronik dan diakronik dengan hasil penelitian terdahulu (penelitian Prof. Sandi Siregar dan penelitian lainnya).

\section{PENDEKATAN TEORI TATA $M A S S A$}

Seiring berjalannya waktu, kawasan Pasar Baru telah mengalami transformasi. Transformasi tersebut menyebabkan munculnya berbagai fenomena baru pada kawasan. Merurut Krier (1988:46-55), transformasi dijelaskan sebagai beberapa kemungkinan bentuk yang dihasilkan melalui proses pengubahan unsur-unsur arsitektur berupa titik, garis, bidang, benda pejal, ruang interior, dan ruang eksterior.

Pada kawasan Pasar Baru, transformasi yang terjadi berupa transformasi tipologimorfologi (bentuk) kawasan. Paul-Alan (1994) menjabarkan bahwa istilah type berasal dari bahasa Perancis type atau dari bahasa latin typus, yangkeduanya berasal dari bahasa latin kuno typos yang berarti sebuah hembusan, gambaran, atau figur. Menurut Schulz (1979), terdapat perbedaan antara morfologi dan tipologi. Tipologi dapat diartikan sebagai suatu klasifikasi untuk mengelompokkan bangunan berdasarkan tipe-tipe tertentu, sedangkan morfologi menyangkut perubahan bentuk pada suatu bangunan. Perubahan bentuk tersebut menyangkut kualitas figurasi dalam konteks bentuk dari pembatasan ruang, dimana sistem figurasi ruang tersebut telah terhubung melalui pola hierarki ruang maupun hubungan ruang. (Johnson, 1994)

Transformasi tipologi-morfologi yang terjadi pada kawasan Pasar Baru dapat terlihat dari perubahan tatanan massa bangunan dan ruang yang disertai dengan perubahan kavling. Menurut Nix, Thomas (1949), tata massa adalah pola peletakan massa bangunan yang akan membentuk morfologi suatu kawasan. Penggunaan tipe tatanan massa dipengaruhi oleh lokasi, fungsi bangunan, serta peruntukan lahan (landuse). Berdasarkan tipenya, tatanan massa bangunan dibagi menjadi 2, yaitu tatanan terbuka (open bouwwijze) dan tatanan tertutup (closed bouwwijze).

Hamid Shirvani (1985), dalam bukunya yang berjudul "The Urban DesignProcess" mengkategorikan beberapa elemen pembentuk ruang fisik kota, di antaranya adalah land use, building form and massing, circulation and parking, open space, pedestrian ways, activity support, signage, dan preservation. Dalamskripsi ini, pendekatan teori elemen-fisik spastial yang digunakan adalah land use, building form \& massing, circulation \& parking, open space \& pedestrian ways.

Kelima aspek tersebut dikaitkan dengan teori tipologi-morfologi. Aspek land use dikaitkan dengan tipologi fungsi bangunan dan kawasan. Aspek building form \&massing dikaitkan dengan aspek tipologi-morfologi tata massa bangunan. Aspek circulation dikaitkan dengan teori tipologi-morfologi dalam pembahasantransformasi sirkulasi kantong, sedangkan pedestrian ways dikaitkan dengan disertasi Prof. Sandi mengenai arcade.

Terdapat dua objek pembahasan dalam skripsi ini, yaitu blok dan koridor. Blok merupakan suatu area yang berada di kota yang dikelilingi oleh jalan pada semua sisinya (Lang, 2006). Menurut Siregar (2013), suatu blok dapat berukuran besar maupun kecil. Suatu blok kota dapat disebut sebagai suatu bangunan tunggal besar atau kumpulan ratusan bangunan yang tersusun rapat maupun renggang. Koridor adalah salah satu komponen dari urban yang 
berbentuk linear yang tertutup di kedua sisinya tetapi dipersatukan oleh dinding-dinding di sekitarnya (Spreiregen, 1965). Menurut Krier (1979), koridor adalah salah satu bentuk dari jalan yang berupa ruang pergerakan linear dan digunakan sebagai sirkulasi. Karakteristik sebuah koridor ditentukan oleh bangunan dan aktivitas yang terdapat pada koridor tersebut.

\section{PEMBAHASAN}

\subsection{SEJARAH PASAR BARU}

Pada saat massa pemerintahan Belanda tahun 1810, dibangun jalur Groote postweg yang melintang secara horizontal dari barat ke timur KotaBandung yang merupakan pemicu perkembangan kota. Setelah itu dibangun Jalan Pangeran Soemedangweg (Jalan Otto Iskandar Dinata) yang memotong tegak lurus jalur Groote postweg. Pembangunan kedua jalan utama tersebut mengakibatkan terbentuknya kawasan baru di sebelah barat alun-alun. ${ }^{2}$

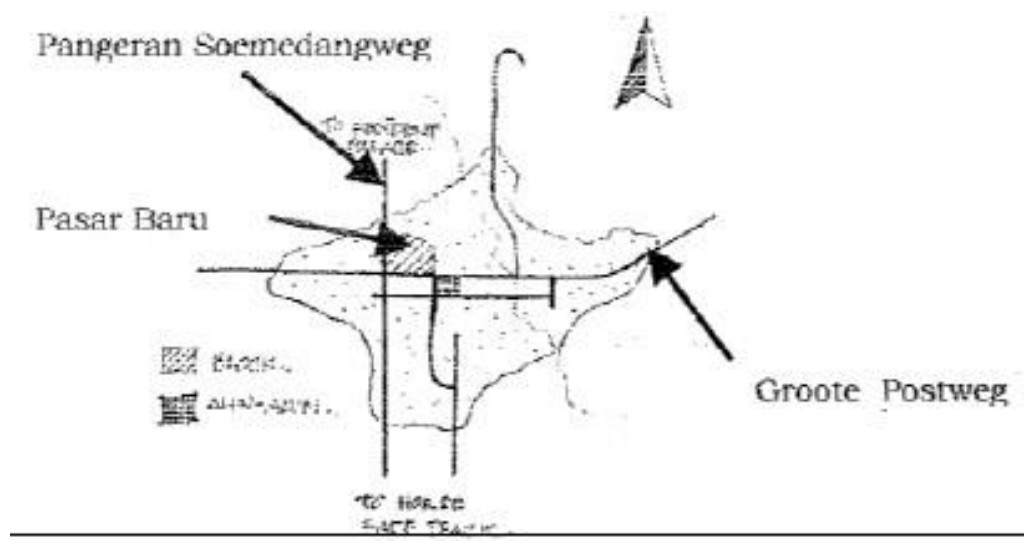

Figur 1. Peta Pembentukan Kawasan Pasar Baru

(Sumber: Siregar, Sandi A., Bandung - the Architecture of a City in Development, 1990)

Pada kawasan tersebut terjadi perpindahan para pedagang dari Pasar Lama yang hangus terbakar ke perkampungan penduduk dan kemudian diberi nama Pasar Baru. Pasar tersebut menjadi cikal bakal pembentukan kawasan perdagangan pusat kota di Bandung. Dibangunnya Stasiun Kereta Api Suniaraja menyebabkan kawasan tersebut bertumbuh semakin cepat dan menjadikan Kota Bandung sebagai kota transit bagi penumpang kerata api. Akibatnya terjadi perkembangan blok dan jalan di sekitar Pangeran Soemedangweg. Jalan-jalan tersebut adalah Jalan ABC, Alkateri, Pecinan Lama, Banceuy dan Suniaraja.

\subsection{FUNGSI BANGUNAN PADA KAWASAN PASAR BARU}

Fungsi komersial yang cenderung dominan menggeser fungsi hunian yang berada pada kawasan tersebut. Bila dilihat berdasarkan RTRW kota Bandung Tahun 2011-2031, kawasan Pasar Baru dan sekitarnya diperuntukkan sebagai kawasan komersial dan perdagangan. Namun pada kenyataannya fungsi bangunan pada kawasan tersebut tidak sepenuhnya sebagai fungsi komersial, beberapa diantaranya merupakan jasa (bank), hunian yang terdapat di tengah blok, dan masjid yang berada di Blok Dulatip Bawah.

\footnotetext{
${ }^{2}$ Siregar, S. A., 1990. Bandung - the Architecture of a City in Development: urban analysis of a regioncapital as a contribution to the present debate on Indonesia urbanity and architectural identity.

Katholieke Universiteit te Leuven: 1990
} 
Bangunan pada outer block yang pada awalnya cenderung mixed-use (hunian dan komersial) sebagai rumah-toko mulai ditinggalkan dan hanya berfungsi sebagai fungsi komersial (hunian dijadikan gudang), walaupun beberapa diantaranya tetap bertahan. Fungsi mixed-use lain yang ditemukan adalah fungsi jasa dan komersial.

\subsection{PERKEMBANGAN TATA MASSA BANGUNAN TAHUN 1990-2015}

Tata massa bangunan pada outer block kawasan Pasar Baru cenderung memiliki tatanan Gesloten Bouwwijze yang berada pada GSB 0. Pemilihan tatanan Gesloten Bouwwijze disesuaikan dengan tipologi rumah-toko pada kawasan pusatkota yang memiliki tuntutan kebutuhan ruang yang tinggi dan terbatasnya lahan. Perubahan tata massa kawasan Pasar Baru terjadi pada beberapa blok. Perubahan yang terjadi berupa penggabungan massa menjadi lebih besar yang disertai dengan penggabungan dan pembelahan kavling menjadi beberapa unit. Perubahan tata massa tersebut terjadi karena perluasan banguna secara horizontal maupun vertikal. Hal ini menyebabkan munculnya fenomena-fenomena baru yang mempengaruhi tipologi-morfologi kawasan Pasar Baru.

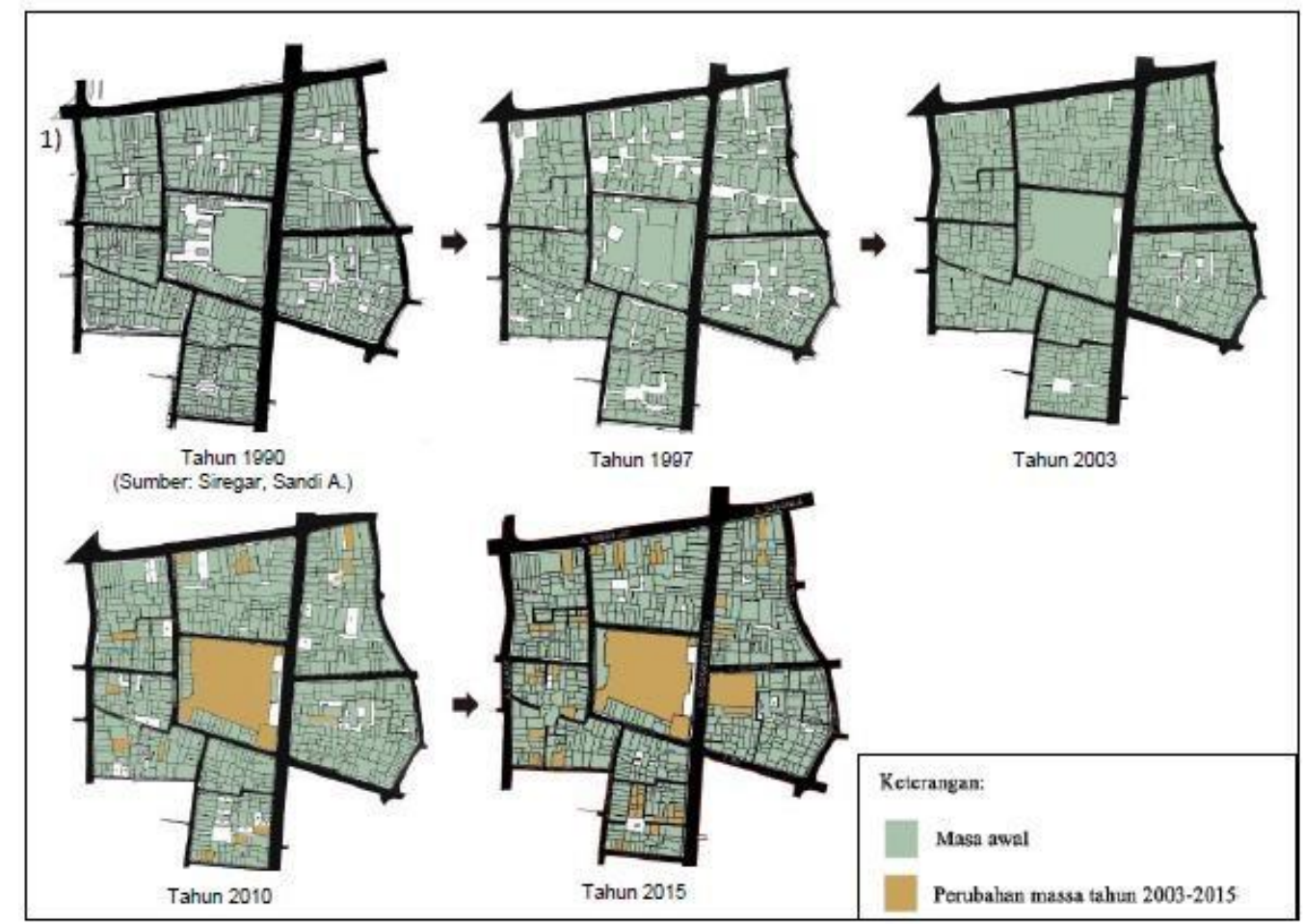

Figur 2. Perkembangan Tata Massa Bangunan Tahun 1990-2015

\subsection{RUANG TERBUKA PADA KAWASAN PASAR BARU}

Pada kawasan ini cenderung padat dan hanya memiliki sedikit area terbuka. Area terbuka pada kawasan ini terbagi menjadi 2, yaitu ruang terbuka linear dan ruang terbuka terpusat, dimana ruang terbuka linear berupa jalan dan sirkulasi gang pada blok, sedangkan ruang terbuka terpusat berupa ruang terbuka hijau yang berada di selatan Blok Tamim. Tidak terdapat area hijau linear yang berupa deretan pepohonan pada kawasan. Hal ini dikarenakan adanya arcade yang berada tepat di atas jalur pedestrian. 


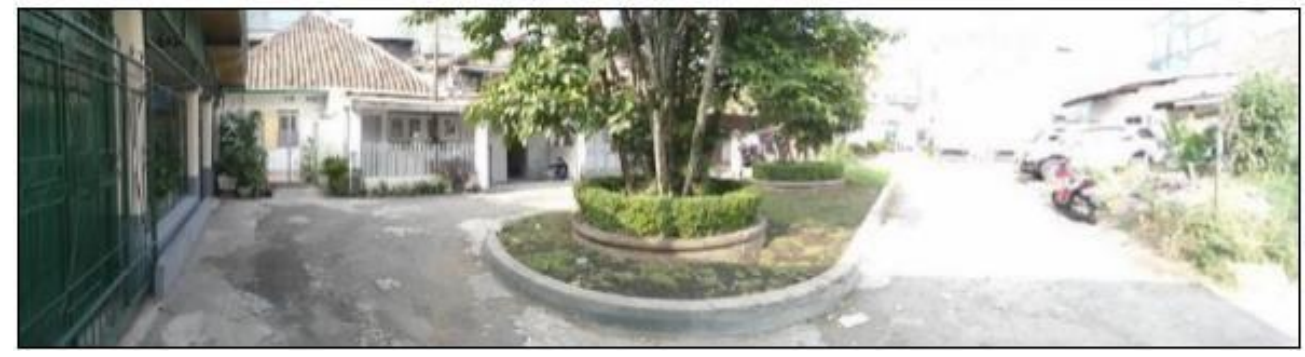

Figur 3. Perspektif Ruang Terbuka pada Blok Jalan Tamim dan Jalan Otto Iskandar Dinata

\subsection{TRANSFORMASI BLOK (RING \& POCKET)}

Pertumbuhan kawasan pusat kota yang semakin padat telah menimbulkanperubahan pada kawasan Pasar Baru, diantaranya adalah perubahan kavling, ketinggian bangunan, bentuk dan tatanan massa bangunan. Perubahan tersebut yang menjadi pemicu munculnya transformasi tata massa maupun ruang pada berbagai blok di kawasan. Pada penelitian ini, pembahasan difokuskan pada Blok Tamim, Blok Alkateri dan Blok Suniaraja.

\subsubsection{TRANSFORMASI KANTONG PERMUKIMAN (POCKET)}

Perluasan bangunan secara horizontal (ke arah dalam blok) menyebabkan terjadinya perubahan bentuk dan dimensi kantong. Teradapat kantong permukiman yang telah terhimpit (subtraktif/hilang) oleh perpanjangan bangunan komersial pada outer block ke arah dalam.

Pada beberapa blok, kantong tak sepenuhnya berupa kantong permukiman, namun beberapa diantaranya berupa tempat parkir dan rumah-toko. Berikut dijabarkan transformasi kantong yang terjadi pada masing-masing blok.

\subsubsection{BLOK TAMIM (JL. TAMIM-JL. OTTO ISKANDAR DINATA)}

Kantong pada blok Tamim tidak terlalu banyak mengalami perubahan. Dimensi kantong mengalami subtraktif pada sisi timur.

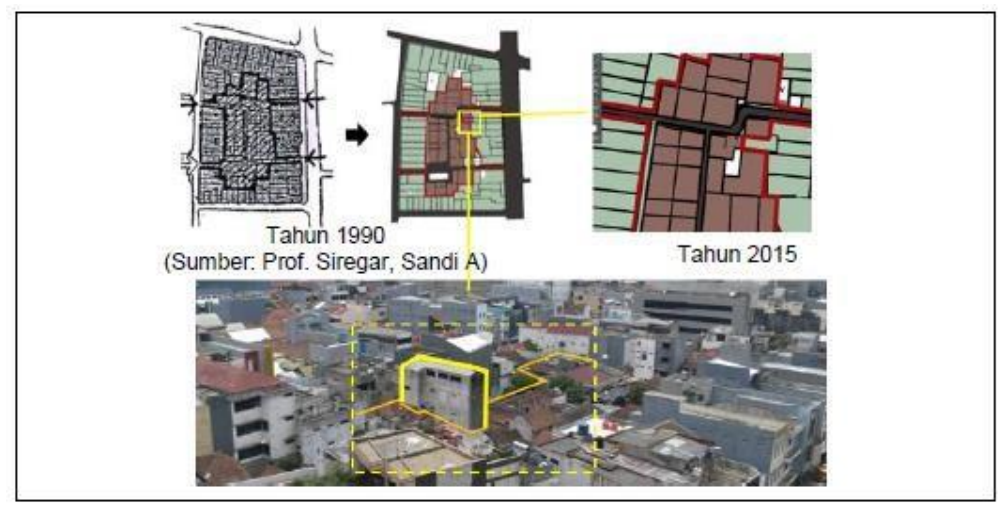

Figur 4. Kantong Permukiman yang Mengalami Subtraktif Akibat Perluasan Bangunan Komersial Ke Arah Dalam Blok

\subsubsection{BLOK ALKATERI (JL. ALKATERI-JL. OTTO ISKANDAR DINATA)}

Blok ini cenderung relatif tetap, namun terjadi sedikit perubahan pada bagian selatan tepi kantong yang mengalami subtraktif. 


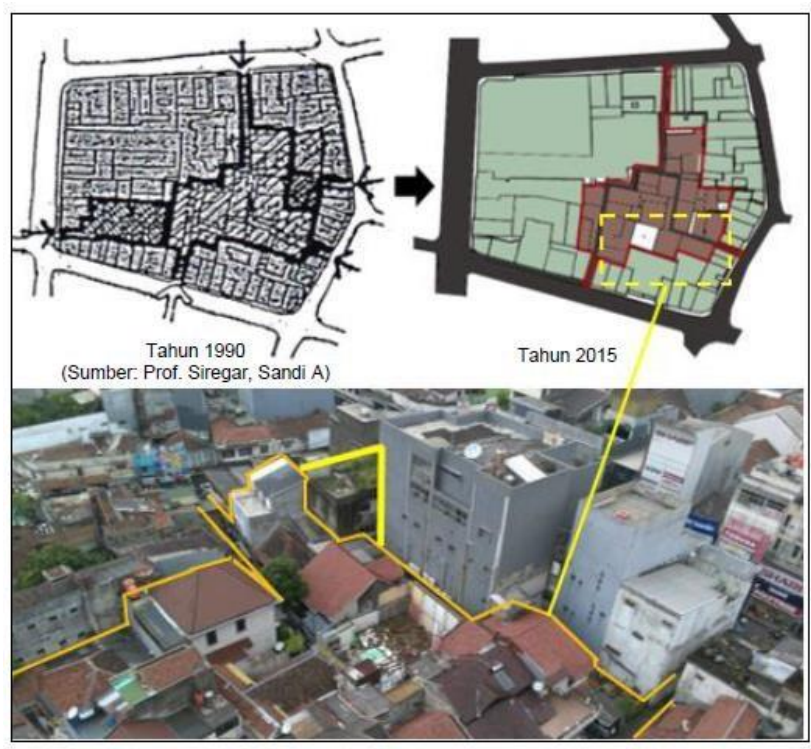

Figur 5. Kantong Permukiman Blok Alkateri yang Telah Mengalami Subtraktif Akibat Pergeseran Luas Bangunan Komersial ke Arah Dalam Blok

\subsubsection{BLOK SUNIARAJA (GANG SUNIARAJA-JL. OTTO ISKANDAR DINATA}

Terjadi perubahan kantong pada sisi utara dan selatan blok Suniaraja. Salah satu kantong pada bagian utara blok telah hilang, sedangkan kantong lainnya hanya berfungsi sebagai area parkir motor. Kantong pada bagian selatan blok mengalami perluasan ke arah jalan buntu.

\subsubsection{BLOK PASAR UTARA (JL. PASAR UTARA-JL. OTTO ISKANDAR DINATA)}

Blok Pasar Utara Blok mengalami transformasi kantong terbuka (open pocket) telah menjadi tertutup (closed pocket) yang disertaipelebaran dimensi kantong.

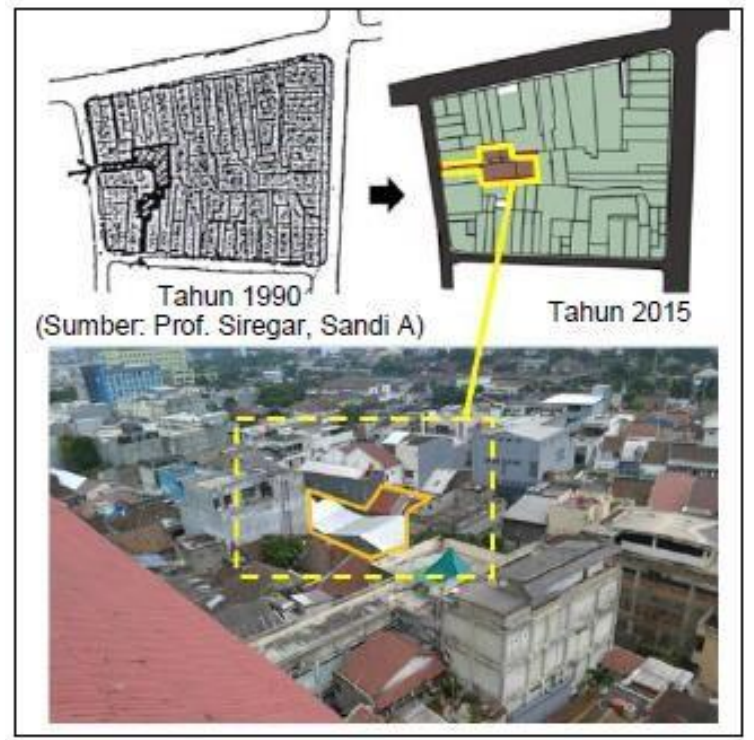

Figur 6. Perubahan Kantong pada Bagian Barat Kantong Blok Pasar Utara 


\subsubsection{BLOK DULATIP ATAS (JL. DULATIP-JL. PASAR BARAT)}

Blok ini mengalami subtraksi kantong pada bagian utara blok yang disebabkan oleh pelebaran bangunan komersial pada outer block.

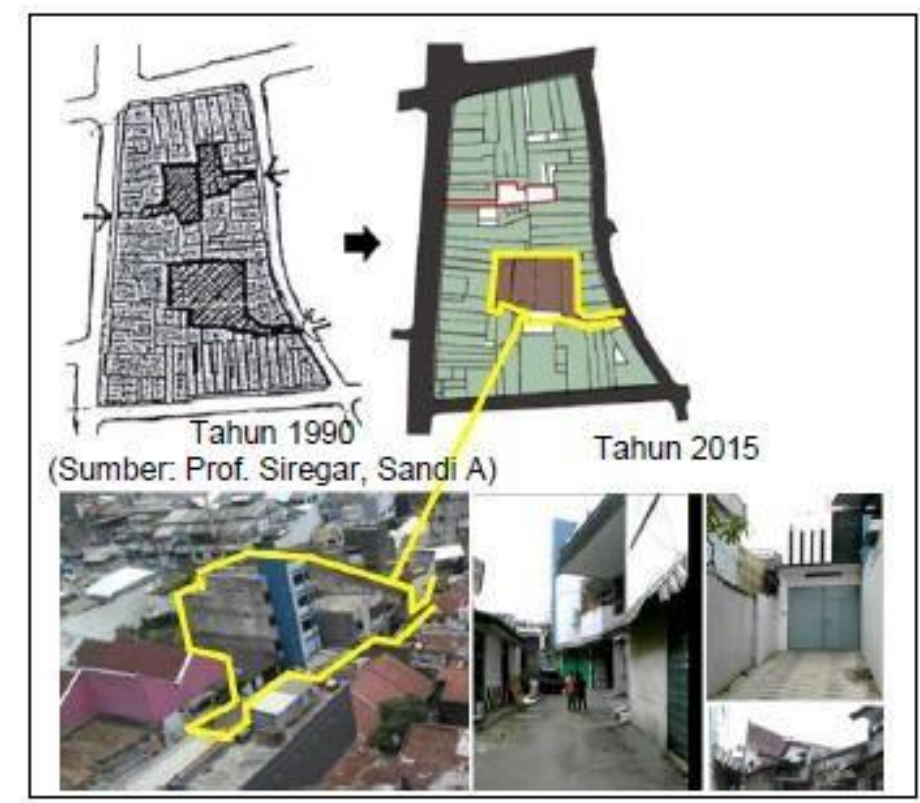

Figur 7. Perubahan Dimensi Kantong pada Bagian Selatan Blok Suniaraja

\subsubsection{BLOK DULATIP BAWAH (JL. DULATIP-JL. PASAR SELATAN)}

Perubahan bentuk kantong permukiman yang paling dominan terjadi pada Blok Dulatip Bawah. Kantong pada blok relatif terhimpit dan mengecil. Pada blok tersebut terdapat kantong lainnya yang mengalami perlebaran ke arah dalam blok dan menghimpit kantong permukiman di belakangnya.

\subsubsection{SIRKULASI}

Perubahan tata massa bangunan pada outer block dan inner block menyebabkan terjadinya perubahan sirkulasi pencapaian kantong permukiman. Terdapat sirkulasi yang masih bertahan, berubah maupun telah hilang. Transformasi sirkulasi pada kawasan ini dikategorikan menjadi 2 yaitu, sirkulasi kantong yang tetap bertahan dan sirkulasi kantong yang berubah/hilang. Sirkulasi kantong permukiman yang bertahan berada pada Blok Dulatip Bawah, sedangkan sirkulasi kantong permukiman yang berubah maupun hilang berada pada Blok Dulatip Atas, Blok Alkateri, Blok Suniaraja, dan Blok Pasar Utara dan Blok Tamim.

\subsubsection{ORIENTASI DAN TATANAN}

Perkembangan kawasan Pasar Baru baik dari segi fisik dan non-fisik menyebabkan terjadi perubahan orientasi bangunan. Orientasi bangunan cenderung tidak teratur, walaupun antar bangunan tertata frontto front pada sepanjang gang. Berikut dijabarkan satu per satu mengenaiorientasi dan tatanan bangunan pada beberapa blok di kawasan Pasar Baru.

\subsubsection{BLOK TAMIM (JL. TAMIM-JL. OTO ISKANDAR DINATA)}

Orientasi pada Blok Tamim menghadap jalan dengan tatanan front to front. Pada outer blok bangunan berorientasi ke jalan utama dan membelakangi kantong permukiman yang 
berada di belakangnya. Pada kantong, bangunan cenderung berorientasi ke jalan sepanjang gang dengan tatanan front to front dan saling membelakangi bangunan lain yang berada di belakangnya (tatanan back to back). Terdapat bangunan yang berorientasi ke taman dengan tatanan front to front pada selatan blok.

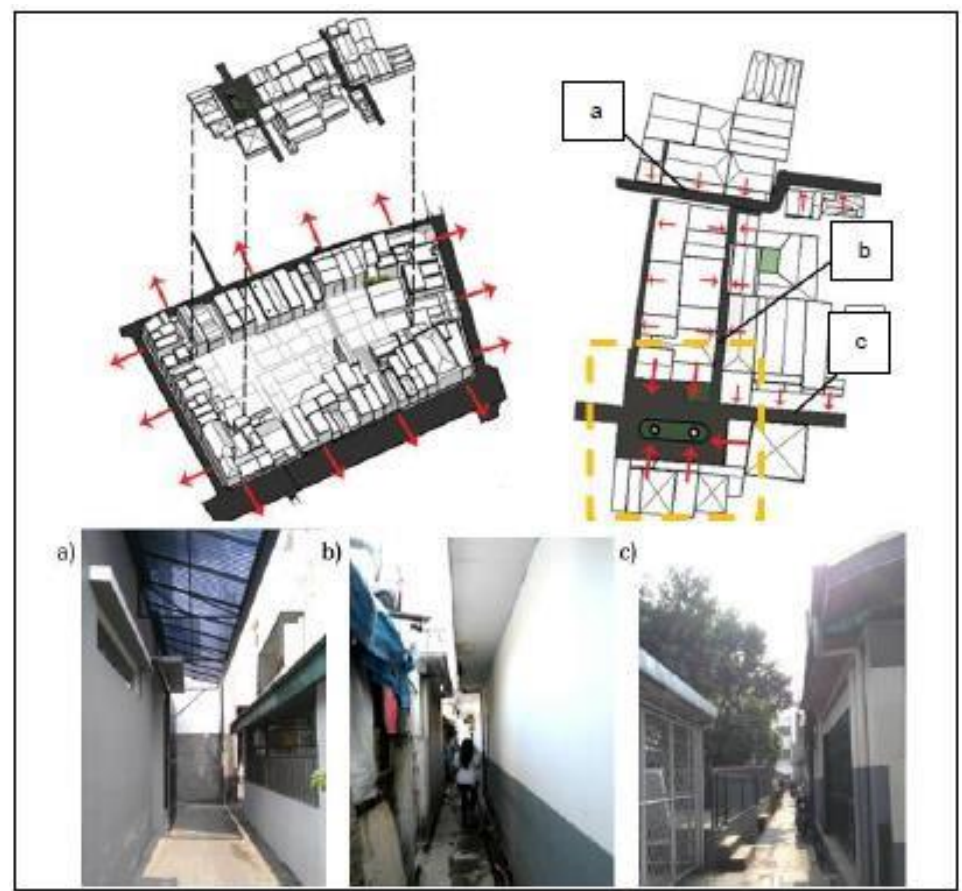

Figur 8. Orientasi dan Tatanan Bangunan pada Blok Tamim

\subsubsection{BLOK ALKATERI (JL. ALKATERI-JL. OTTO ISKANDAR DINATA)}

Orientasi bangunan pada Blok Alkateri tidak teratur dibandingkan Blok Tamim. Orientasi bangunan tidak semuanya menghadap jalan sepanjang gang, terdapat beberapa diantaranya yang membelakangi gang dan berorientasi ke arah lapisan terluar blok.

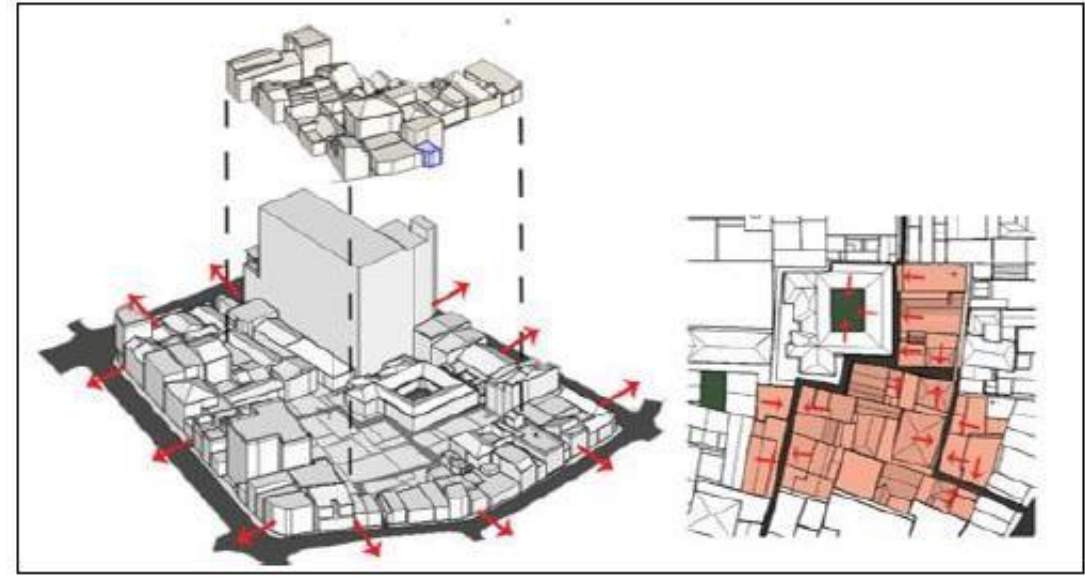

Figur 9. Aksonometri Tatanan dan Orientasi Bangunan pada Blok Alkateri Tahun 2015

\subsubsection{BLOK SUNIARAJA (JL. SUNIARAJA-JL OTTO ISKANDAR DINATA)}

Blok ini memiliki tatanan orientasi bangunan yang tidak beraturan dibandingkan yang lainnya. Terjadi perubahan fungsi rumah-industri yang berada di dalam kantong bagian selatan. Hal tersebut menyebabkan terjadi perubahan orientasi bangunan dan tatanan yang heterogen 
dan kacau. Pada bagian outer block cenderung berorientasi ke arah jalan utama dengan tatanan (back toback) terhadap kantong. Pada kantong di bagian selatan blok, orientasi bangunan cenderung menghadap jalang pada gang dengan tatanan front to back.

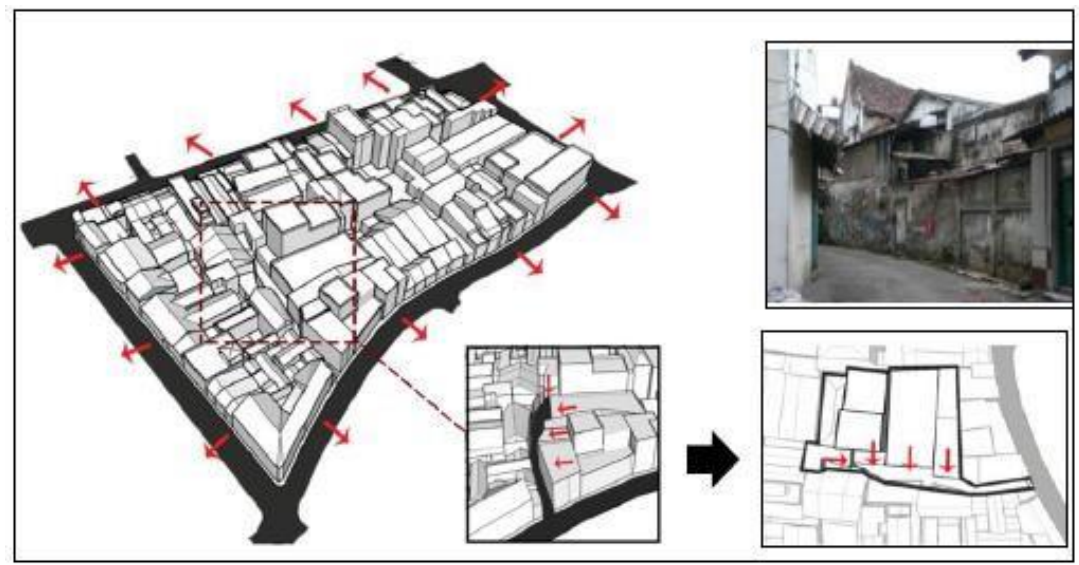

Figur 10. Gambar Orientasi dan Tatanan Bangunan pada Blok Suniaraja

\subsubsection{TRANSFORMASI SKALA}

Perkembangan bangunan komersial ke arah vertikal yang terjadi menyebabkan terjadinya kesenjangan skala bangunan. Bangunan komersial yang tinggi berbanding terbalik dengan fungsi hunian yang cenderung rendah yakni berkisar 1-2 lantai. Perbedaan skala inilah yang kemudian menjadi batas pemisah antara bagian tepi (outer block) dan kantong permukiman. Berikut dijabarkan fenomena kesenjangan skala pada beberapa blok.

\subsubsection{BLOK TAMIM (JL. TAMIM-JL. OTO ISKANDAR DINATA)}

Perubahan skala bangunan pada Blok Tamim terjadi pada bagian timur blok yang berbatasan dengan koridor utama Jl. Otto Iskandar Dinata, namun ketinggian bangunan pada kantong relatif sama yaitu berkisar 1-2 lantai dengan skala bangunan yang relatif kecil. Perbedaan ketinggian inilah yang kemudian menimbulkan kesenjangan skala bangunan pada bagian outer dan inner block yang cenderung membentuk ring.

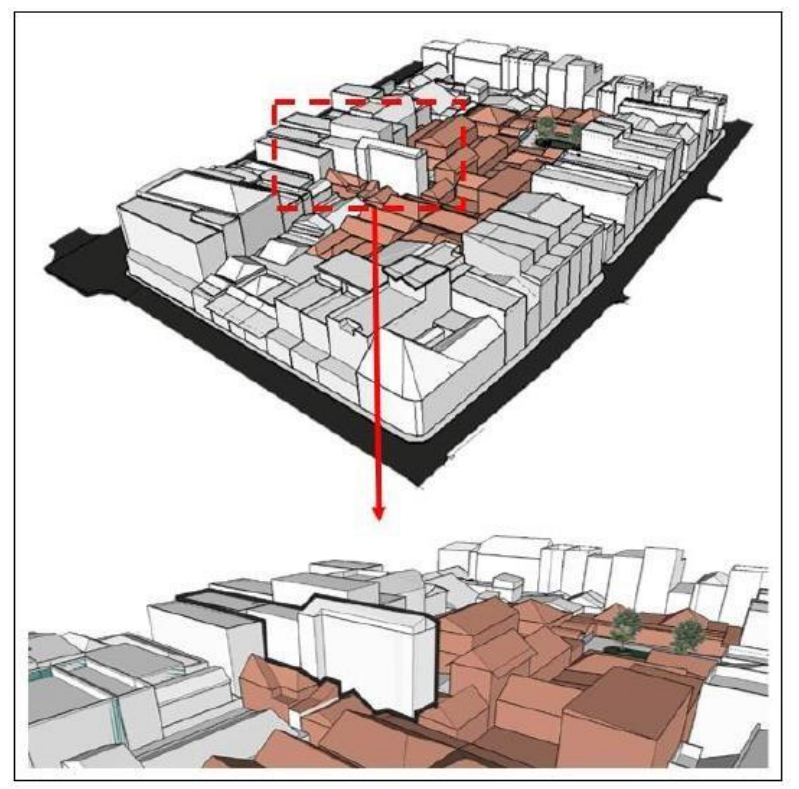




\subsubsection{BLOK ALKATERI (JL. ALKATERI-JL. OTTO ISKANDAR DINATA)}

Pada blok Alkateri terjadi transformasi skala bangunan yang dominan berada di bagian barat blok, sedangkan pada bagian utara dan timur blok relatif sama. Pada bagian barat blok terjadi penggabungan kavling menjadi satu kesatuan massa bangunan yangcenderung besar dan tingginya lebih dari 10 lantai. Perubahan skala yang signifikan menyebabkan terjadinya kesan kontras pada kawasan.

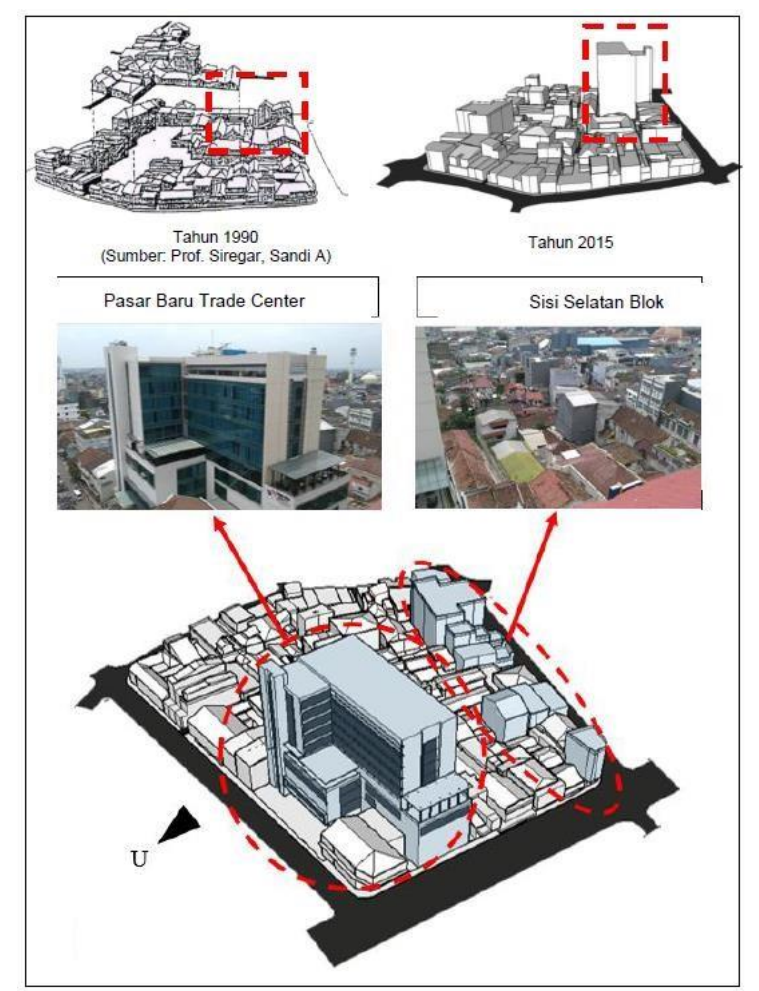

Figur 12. Bangunan Tinggi yang Mendominasi Blok Alkateri

\subsubsection{BLOK SUNIARAJA (JL. SUNIARAJA-JL OTTO ISKANDAR DINATA)}

Perubahan tata massa bangunan tidak terlalu banyak. Skala bangunan pada blok ini relatif sama dengan massa bangunan yang besar, memanjang dan tinggi. Hal ini menyebabkan tidak ditemukannya kesenjangan massa bangunan outer block terhadap kantong. Pada bagian selatan blok, massa bangunan pada kantong relatif tinggi, sehingga menyebabkan munculnya tatanan massa bangunan dengan skala tinggi pada tengah-tengah inner block. 


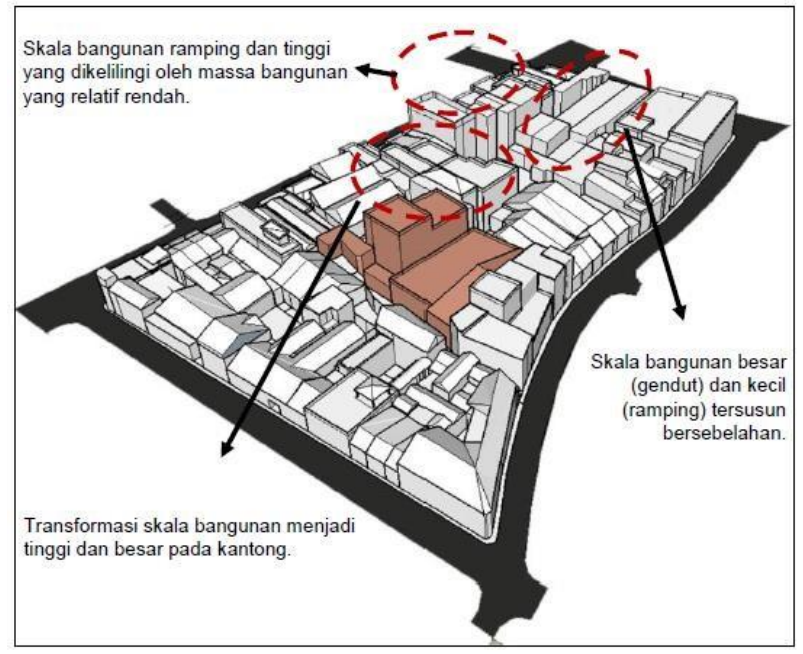

Figur 13. Skala Bangunan pada Blok Suniaraja

\subsection{TRANSFORMASI KORIDOR JALAN OTTO ISKANDAR DINATA}

\subsubsection{STREETSIDE FABRIC}

Perkembangan kawasan Pasar Baru sebagai kawasan komersial di tengah kepadatan kota menyebabkan ditinggalkannya fungsi hunian pada kawasan tersebut. Terjadi perubahan fungsi hunian pada rumah-toko menjadi gudang guna menunjang fungsi komersial, walaupun beberapa diantaranya tetap. Minimnya hunian pada koridor menyebabkan kawasan tersebut menjadi mati pada malam hari. Perubahan fungsi ini menyebabkan terjadinya perubahan fasad bangunan pada sepanjang koridor Jalan Otto Iskandar Dinata. Terdapat beberapa fasad bangunan yang masif (ditutup seng) tanpa diberi bukaan, khususnya bangunan yang telah ditinggalkan dan tidak difungsikan. Pada bagian timur koridor terdapat bangunan lama yang telah mengalami perubahan fasad muka bangunan. Toko mas sari Murni mengalami penutupan bovenlicht menjadi dinding masif. Penutupan fasad bangunan diduga muncul sebagai akibat pertimbangan faktor keamanan penghuni.
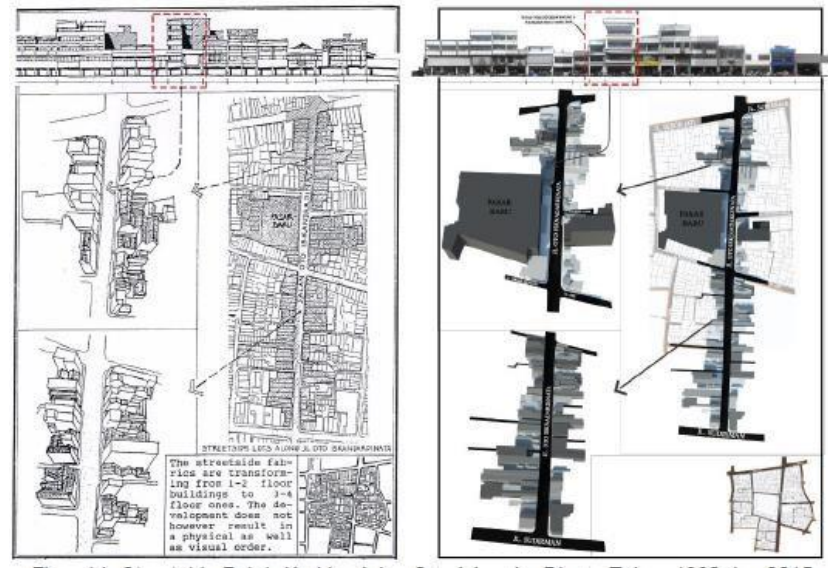

Figur 14. Streetside Fabric Koridor Jalan Otto Iskandar Dinata Tahun 1990 dan 2015 


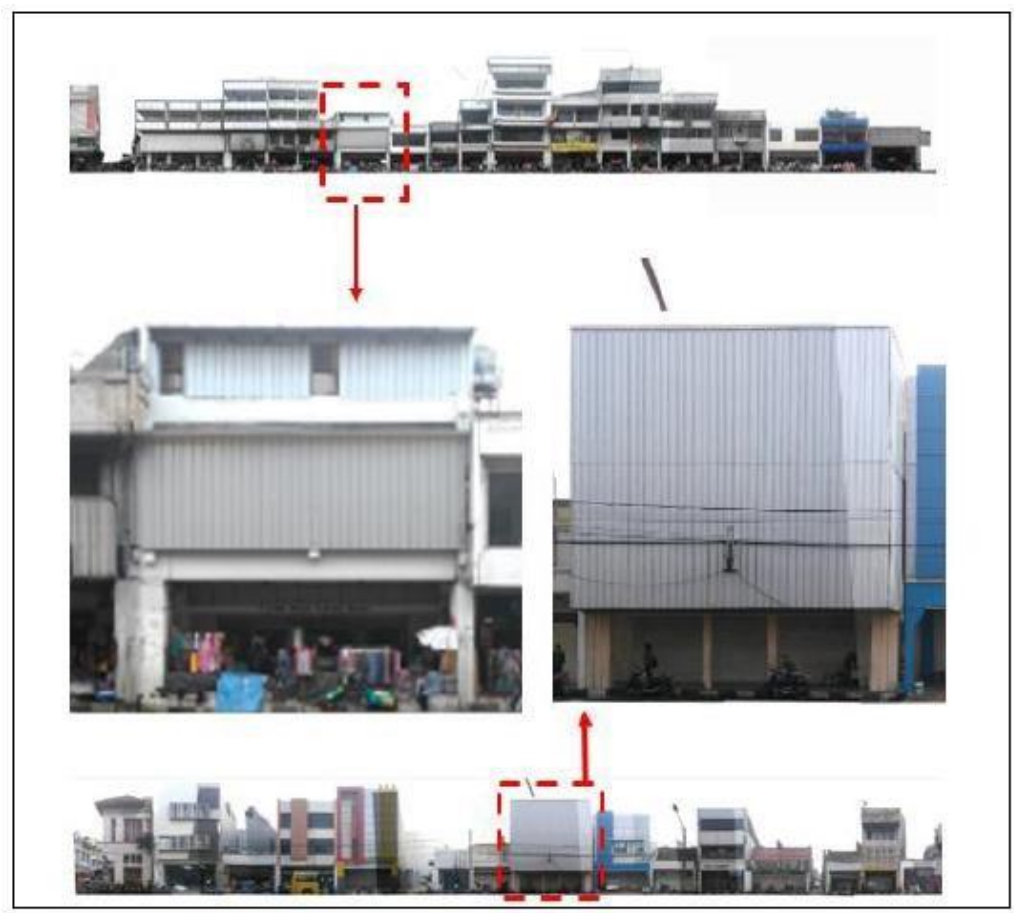

Figur 15. Penutup Fasad Bangunan pada Koridor Jalan Otto Iskandar Dinata

Perbedaan ketinggian bangunan sepanjang koridor yang heterogen menciptakan wajah kota yang relatif bervariasi. Dibangunnya bangunan Pasar Baru Trade Center dan gedung baru Pasar Baru Trade Center yang memiliki ketinggian lebih dari 10 lantai telah mendominasi bangunan-bangunan kecil dan rendah yang berada di sekitarnya. Hal ini menyebabkan terjadinya kesenjangan bangunan yang merusak wajah kota.

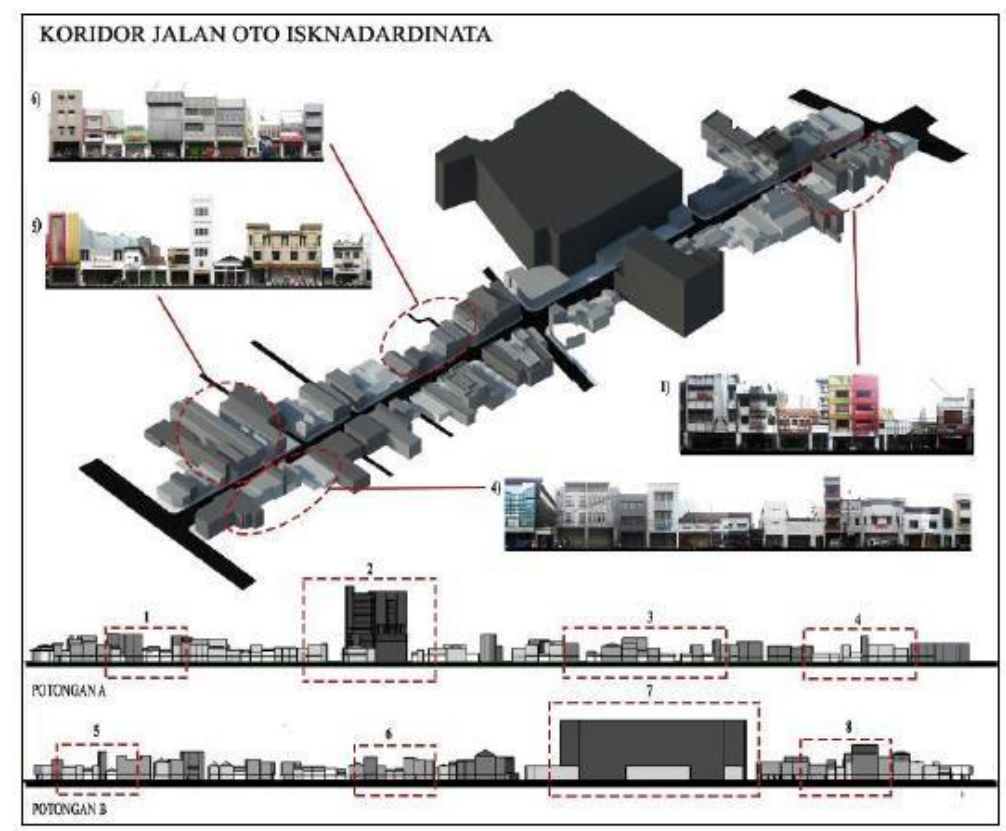

Figur 16. Ketinggian Bangunan pada Koridor Jalan Otto Iskandar Dinata 


\subsubsection{ARCADE OF THE STREET ROAD}

Perkembangan kawasan Pasar Baru sebagai kawasan komersial menyebabkan munculnya tipologi fasad bangunan berupa arcade yang mengelilingi outer block kawasan dengan fungsi dibawahnya sebagai jalur pedestrian. Saat ini terjadi pemutusan arcade di beberapa titik. Bank Bumi Arta, gedung Pasar Baru Trade Center lama dan baru menerapkan sistem set back yang menyebabkan terputusnya arcade. Jalur pedestrian tetapada namun tidak dilengkapi dengan arcade.

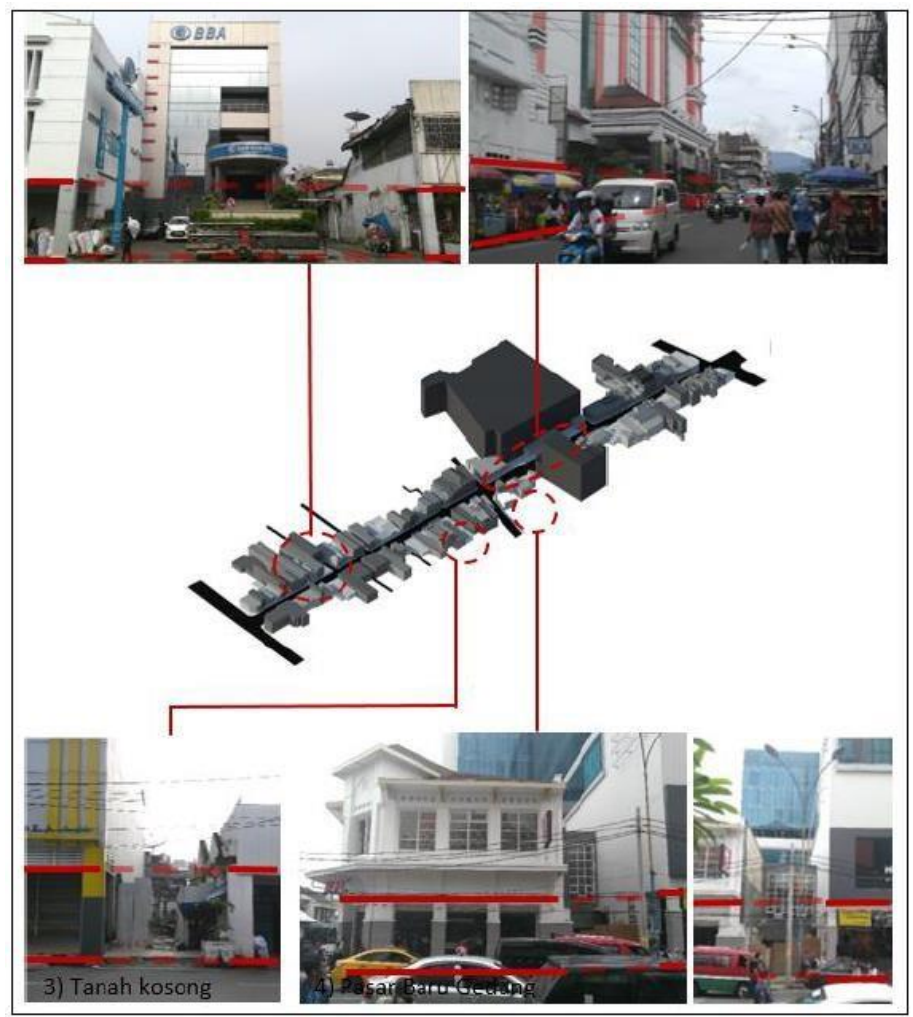

Figur 17. Arcade Sepanjang Koridor Jalan Otto Iskandar Dinata

\subsubsection{MUNCULNYA PINTU MASUK GANG YANG TIDAK TERDEFINISI}

Tuntutan GSB 0 menciptakan beberapa perubahan pada tata massa bangunan maupun sirkulasi gang. Pada kawasan ini dijumpai perubahan pintu masuk gang yang telah mengalami pembangunan massa bangunan maupun atap yang disesuaikan dengan tatanan massa lainnya yang berada di GSB 0. Fenomena pintu masuk gang yang memiliki lebar yang kecil ini mempengaruhi tipologi masa sekitarnya. Bangunan tersebut terlihat sebagai satu kesatuan dengan massa lainnya, namun bila ditelusuri lebih dalam bangunan tersebut merupakan akses masuk menuju gang. 


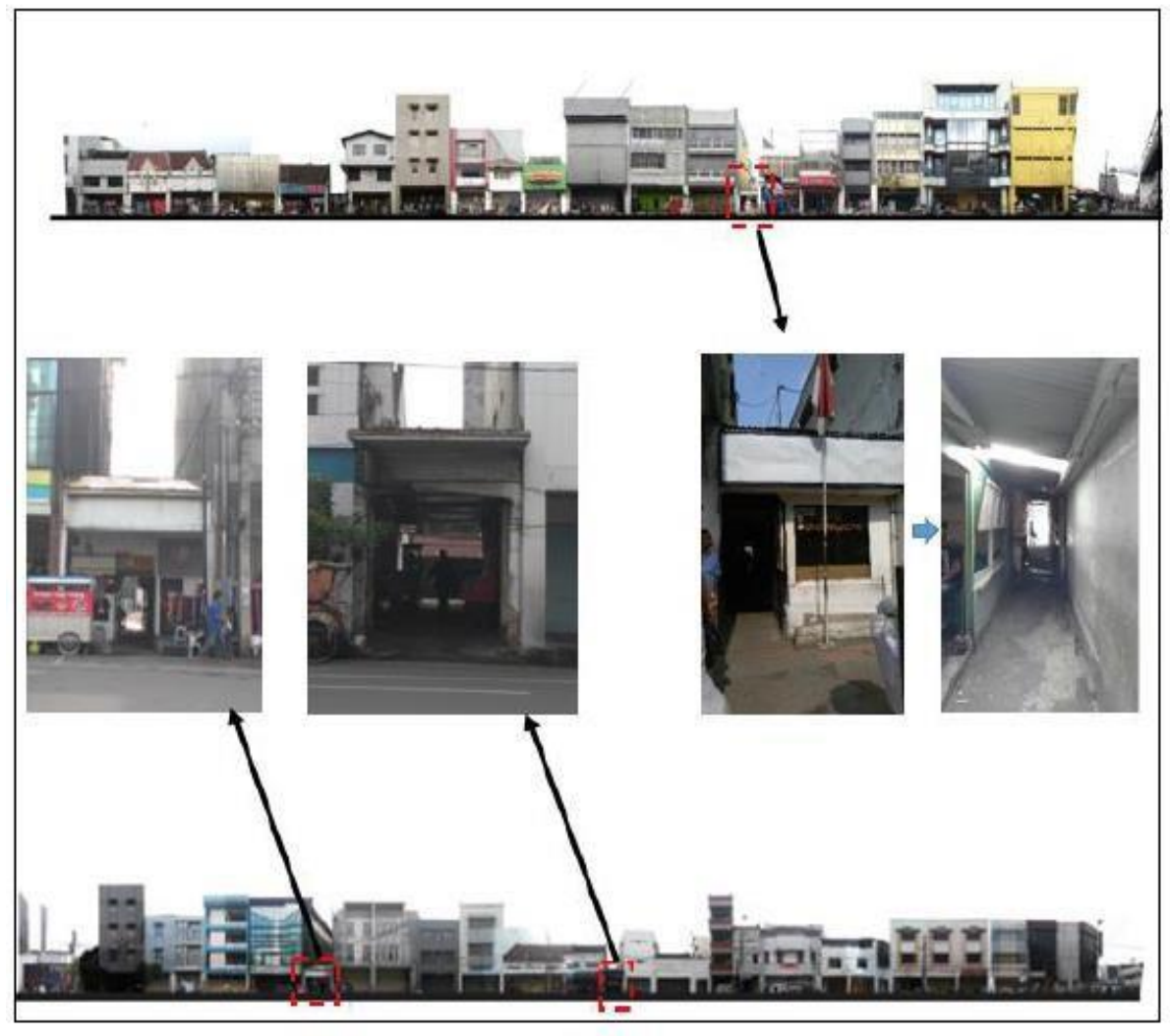

18. Gambar Pintu Masuk Gang yang Tak Terdefinisi

\section{KESIMPULAN}

Berdasarkan penelitian ini dapat disimpulkan bahwa Pasar Baru merupakan salah satu kawasan pusat kota yang mengalami perkembangan dan transformasi yang signifikan. Tuntutan fungsi komersial pada kawasan tersebut menyebabkan munculnya perubahan tata massa bangunan yang telah mempengaruhi tipo-morfologi blok kawasan. Perubahan tatanan massa dan ruang tersebut muncul akibat terjadinya perluasan bangunan ke arah vertikal dan horizontal yang disertai dengan penggabungan dan pembelahan kavling. Perubahan inilah yang kemudian telah mempengaruhi perubahan tipo-morfologi blok dan koridor Jalan Otto Iskanda Dinata, baik dari segi skala, ketinggian, orientasi, blok massa dan fungsi bangunan. Transformasi tata massa bangunan memberikan berbagai dampak pada blok dan koridor Jalan Otto Iskandar Dinata. Pada beberapa blok telah mengalami perubahan tata massa pada lapisan terluar yang berbatasan langsung dengan jalan. Perubahan ini menimbulkan berbagai dampak bagi kawasan tersebut, termasuk kantong. Kantong permukiman yang berada pada bagian terdalam blok terhimpit dan mengalami penyempitan (subtraktif), bahkan terdapat kantong yang telah hilang pada Blok Suniaraja. Pada Blok Pasar Utara, terjadi perubahan kantong yang pada awalnya terbuka menjadi tertutup.

Dampak lainnya dapat terlihat adalah perubahan akses masuk menuju kantong yang telah berubah/hilang, walaupun terdapat beberapa diantaranya yang tetap bertahan dan tidak berubah. Pada beberapa blok mengalami perubahan akses masuk menuju kantong, dan beberapa di antaranya telah hilang. Namun terdapat pula beberapa akses menuju blok yang tetap bertahan dan tidak berubah. Blok yang bertahan adalah Blok Dulatip Bawah, sedangkan blok yang mengalami perubahan ataupun hilang adalah Blok Tamim, Blok Dulatip Atas, Blok Pasar Utara, Blok Suniaraja, Blok Alkateri. 
Perluasan bangunan secara vertikal yang terjadi pada kawasan Pasar Baru dan sekitarnya baik dari ketinggian dan skala bangunan yang relatif berbeda) telah menyebabkan terjadinya kesenjangan skala pada kawasan Pasar Baru, khusunya pada setiap blok. Hal ini kemudian menimbulkan kesan kontras pada perbatasan outer dan inner block, namun skala bangunan pada Blok Suniaraja cenderungmerata dan tidak terlalu kontras.

Perubahan tata massa dan ruang juga telah mempengaruhi koridor Jalan Otto Iskandar Dinata. Perubahan peruntukkan fungsi menyebabkan terjadinya berbagai perubahan tipologi fasad bangunan sepanjang koridor. Hal ini diperkuat dengan adanya bangunan masif yang memiliki bukaan yang relatif sedikit. Pada sisi timur koridor dijumpai bangunan tradisional 1 lantai yang mengalami penutupan bovenlicht. Tipologi fasad yang cenderung heterogen menyebabkan fasad memiliki style yang berbeda dan berantakan.

Dampak lainnya yang muncul adalah terjadinya kesenjangan skala bangunan di sepanjang koridor yang diakibatkan oleh persebaran ketinggian dan skala bangunan yang tidak merata. Selain itu pada beberapa titik terdapat arcade yang telah terputus akibat set back Gedung Bank Bumi Arta, Pasar Baru Trade Center. Tuntutan tatanan GSB 0 pada koridor Jalan Otto Iskandar Dinata menyebabkan munculnya unidentify alley entrances. Pada kasus ini, terjadi perubahan pintu masuk menuju kantong yang telah mengalami penambahan massa bangunan pada bagian atasnya (berupa gapura maupun shelter). Secara kasat mata pintu masuk tersebut terlihat sebagai massa baru, namun pada kenyataannya bangunan terebut merupakan pintu masuk kantong.

Dapat disimpulkan bahwa berbagai fenomena tersebut telah menciptakan keanekaragaman tipologi fasad bangunan pada kawasan tersebut, baik dari segi tata massa, skala, ruang, orientasi, dan ketinggian bangunan. Keanekaragaman tersebut menciptakan wajah kota yang relatif heterogen. Pasar Baru identik dengan kantong permukiman yang berada di dalam blok. Kantong permukiman tersebut tetap bertahan walaupun telah terjadi berbagai fenomena yang menghimpit dan mendominasi kantong tersebut. Berdasarkan penelitian ini dapat dilihat bahwa kawasan tersebut akan terus mengalami transformasi tata massa. Pada kawasan tersebut akan mengalami pembangunan ke arah vertikal dengan blok massa bangunan yang relatif besar. Sedangkan kantong permukiman di dalam blok bisa saja menjadi hilang maupun tetap bertahan.

Bila dipandang dari segi regulasi terjadi beberapa indikasi pelanggaran, diantaranya adalah setback bangunan yang seharusnya berada di GSB 0 akibat tuntutan lahan parkir, pembangunan yang melebihi batas KDB (KDB dibangun 100\%) dengan tidak adanya RTH (Ruang Terbuka Hijau), dan perubahan fasad bangunan yang tidak memperhatikan nilai historis kawasan sebagai kawasan preservasi. Perubahan tersebut diijinkan selama masih memperhatikan konteks kawasan Pasar Baru, sehingga tidak terjadi perubahan fasad atau tata massa yang relatif mengubah ciri khas kawasan.

\section{DAFTAR PUSTAKA}

\section{Buku:}

Johnson, P. A. (1994). The Theory of Architecture: Concepts Themes \& Practices. USA: Wiley.

Krier, R. (1988). Architectural Composition. New York: Rizzoli.

Krier, R. (2006). Town Spaces: Contemporary Interpretations in Traditional Urbanism. Boston: Birkhauser.

Lang, J. (2006). The Little Book of Real Estate Definitions Asia Pacific. Singapore: John Wiley \& Sons. 
Schulz, C. (1979). Genius Loci. New York: Rizzoli International Publication.

Shirvani, H. (1985). The Urban Design Process. New York, USA: Van Nostrand Reinhold Company. Spreiregen, P. D. (1965). Urban Design: The Architecture of Towns and Cities. New York: Mc Graw Hill Book Co.

\section{Tesis, dan disertasi:}

Nix, T. 1949. De vormleer van de stedebouw, in het bijzonder voor Indonesie, TH Delft: adoctoral thesis. Heemstede: The Toorts.

Siregar, S. A. 1990. Bandung - the Architecture of a City in Development: urban analysisof a region capital as a contribution to the present debate on Indonesia urbanity and architectural identity. Katholieke Universiteit te Leuven: 1990. 